\title{
On The Use Of Writing Assignments In Intermediate Microeconomic Theory
}

Patrick B. O’Neill, University of North Dakota, USA

\begin{abstract}
A typical writing assignment in upper level required courses is a term paper. However many economics majors, particularly those in business schools, need to develop skill at writing shorter pieces. In this paper I describe numerous examples of shorter writing assignments that I have incorporated into an Intermediate Microeconomic Theory course. The assignments include such activities as comparison of competing theories; non-traditional applications of theory; book reviews; and explorations of the nuances of the standard consumer choice model. In addition to describing the details of the various assignments, the paper presents both student and instructor assessment of them.
\end{abstract}

Keywords: Writing Assignments, Intermediate Microeconomic Theory, Student Reactions

\section{INTRODUCTION}

had an experience in graduate school that is forever etched in my memory. Perhaps you had a similar experience and have a similar memory. In the first week of my first graduate course in Microeconomic Theory, when the instructor was describing the course, he informed the class that we would be required to write a paper. As if of one mind those of us in the class were puzzled. We all knew that Microeconomics is about graphs and equations and Blue Books, not about writing. One brave student expressed this common belief to the instructor. The response: Economists write papers. Economists who are micro theorists write theory papers. This is a course in Microeconomic Theory. You are training to be economists. You will write a paper on microeconomic theory for this course. ${ }^{1}$

Even though most of our undergraduate students will not go on to be professional economists, they will need to express themselves in writing. Since perhaps the best way to become a competent writer is by practice, we should require our undergraduates, even those in an intermediate microeconomic theory course, to practice writing. ${ }^{2}$

In this paper I describe various writing assignments that I have inflicted upon students in my Intermediate Microeconomic Theory course at the University of North Dakota over the past several years. ${ }^{3}$ In addition to a description of the various assignments, I will present some reaction or feedback from the students along with a list of lessons learned.

\section{DESCRIPTION OF THE ASSIGNMENTS}

For several years I have assigned a variety of different writing assignments to my students in Intermediate Microeconomic Theory. The assignments vary in nature, purpose, and scope. The basic format of them all is to read first, write second. Some of the assignments involve reading specific material; sometimes the required reading is lengthy (an entire book or numerous papers); sometimes it is only one paper; sometimes there was no required reading suggested. Sometimes the topic of the essay is given, other times the students are allowed to choose the topic. Even though there is a large amount of variety among the assignments, they all have two basic elements in common: attempting to get the students to view microeconomics in a richer context than that presented in the standard textbooks and having the students write something other than a traditional term paper. Indeed the length of the writing assignments has consistently decreased from 3-6 pages down to 2 pages. The latter with explicit 
instructions indicating the student will be penalized for exceeding the required length. ${ }^{4}$ An overview of each of the assignments is presented below. ${ }^{5}$

\section{Fall 1998} firm.

Two essays: one on an extension of consumer theory and the other on an extension of the theory of the

Purpose: to take a step beyond the textbook treatment of consumer and firm theory. articles:

Nature of assignment: to read an assigned article and write up a 3-6 page summary and reaction paper. The

- $\quad$ Consumer Theory: Rabin, Matthew "Psychology and Economics" Journal of Economic Literature, Vol. 36 March 1998, pages 11-46.

- $\quad$ Theory of the Firm: Penrose, Edith "The Firm in Theory" in The Theory of the Growth of the Firm 3e Oxford University Press, 1995, pages 9-30.

Grading information: each essay was worth $5 \%$ of the course grade.

\section{Fall 1999}

One essay: on the theory of the firm.

Purpose: to take a step beyond the textbook treatment of firm theory.

Nature of assignment: to read several assigned articles and write a 3-5 page essay entitled "On the limited nature of the standard microeconomic theory of the firm." The articles:

- Williamson, Oliver E. “The Modern Corporation: Origins, Evolution, and Attributes” Journal of Economic Literature, Vol. 19 December 1981, pages 1537-1568.

- $\quad$ Nelson, Richard R. "Why Do Firms Differ, and How Does It Matter?" Strategic Management Journal, Vol. 12 Winter 1991 pages 61-74.

- Chandler, Alfred D. "Organizational Capabilities and the Economic History of the Industrial Enterprise" Journal of Economic Perspectives, Vol. 6 No. 3 Summer 1992 pages 79-100.

- $\quad$ Spulber, Donald F. "Economic Analysis and Management Strategy: A Survey" Journal of Economics and Management Strategy, Vol. 1 No. 3 Fall 1992, pages 535-574.

- Bolton, Patrick and Scharfstein, David S. "Corporate Finance, The Theory of the Firm, and Organization" Journal of Economic Perspectives, Vol. 12 No. 4 Fall 1998 pages 95-114.

Grading information: the essay was worth $10 \%$ of the course grade.

\section{Fall 2000}

firm.

Two essays: one on the nature of perfect competition and the other on an extension of the theory of the

Purpose: to take a step beyond the textbook treatments of competition and firm theory.

Nature of assignments:

To read an essay on competition and write a 2-3 page essay responding to some predetermined questions.

The essay: 
- Hayek, Frederick "The Meaning of Competition" Chapter 5 in Individualism and Economic Order, University of Chicago Press, 1948, pages 92-106.

The questions:

- Does Hayek support or criticize the textbook model of perfect competition?

- How can Hayek's analysis be incorporated into economic analysis? Has it been?

To read two articles and write a 2-3 page essay entitled "On the limited nature of the standard microeconomic theory of the firm." The articles:

- $\quad$ Spulber, Donald F. "Economic Analysis and Management Strategy: A Survey" Journal of Economics and Management Strategy, Vol. 1 No. 3 Fall 1992, pages 535-574.

- Bolton, Patrick and Scharfstein, David S. "Corporate Finance, The Theory of the Firm, and Organization" Journal of Economic Perspectives, Vol. 12 No. 4 Fall 1998 pages 95-114.

Grading information: each essay was worth $5 \%$ of the course grade.

\section{Fall 2001}

Two essays: one on consumer theory and the other on the nature of perfect competition.

Purpose: to take a step beyond the textbook treatment of microeconomic theory.

Nature of assignments:

To read a paper on the consumer and the chapter on the Rational Choice Model in the textbook and write a 1-2 page essay that comments on the question "Does the maximization of utility imply happiness?" The essay:

- $\quad$ Rhoads, Steven A. “The Economist's Consumer and Individual Well-Being” Chapter 9 in The Economist's View of the World, Cambridge University Press, 1985, pages 143-178.

To read an essay on competition and the chapter on Perfect Competition in the textbook and write a 1-2 page essay that comments on the question "Is competition a process or a market structure?" The essay:

- Hayek, Frederick "The Meaning of Competition" Chapter 5 in Individualism and Economic Order, University of Chicago Press, 1948, pages 92-106.

The textbook material read by the students was Chapter 5 "Rational Consumer Choice" and Chapter 11 "Perfect Competition" in Microeconomics and Behavior by Robert Frank

Grading information: each essay was worth $5 \%$ of the course grade.

\section{Fall 2002}

Two essays: one on consumer theory and the other on the theory of the firm.

Purpose: to take a step beyond the textbook treatment of consumer and firm theory.

Nature of assignments:

The students were given possible essay topics and told to pick one from the suggested list or to come up with one of their own (subject to instructor approval). The essays were to be no longer than 2 pages in length. 
Suggested consumer theory essay topics:

- Does the maximization of utility imply happiness?

- What is more important in deciding a best bundle: preferences or constraints?

- "The rational choice model is too restrictive in its characterization of individual behavior." Argue for or against this statement.

- "The opportunity cost of leisure is not labor but rather hell." Argue for or against this statement.

Suggested firm theory essay topics:

- Is competition a process or a market structure?

- $\quad$ "Perfect competition is neither." Argue for or against this statement.

- $\quad$ Do firms really maximize profit?

- $\quad$ "The neoclassical characterization of the firm as an optimizing entity subject to constraints is too restrictive a characterization of the modern business enterprise." Argue for or against this statement.

Grading information: each essay was worth $10 \%$ of the course grade.

\section{Fall 2003}

Two essays: one on consumer theory and the other on the theory of the firm.

Purpose: to take a step beyond the textbook treatment of consumer and firm theory.

Nature of assignments: The students were instructed to find some pertinent reading material and then two write two separate essays, each 2 pages in length, each providing the answer to a specific question. The two questions:

- $\quad$ Does the maximization of utility imply happiness?

- $\quad$ Do firms really maximize profit?

Grading information: each essay was worth $10 \%$ of the course grade.

Fall 2004

Two essays: one on consumer theory and the other on the nature and purpose of a business.

Purpose: to take a step beyond the textbook treatment of consumer and firm theory.

Nature of assignments:

To read a paper and write a 1-2 page analysis (reaction) essay. The paper:

- $\quad$ Kwilecki, Susan and Loretta S. Wilson "Was Mother Teresa Maximizing Her Utility? An Idiographic Application of Rational Choice Theory" Journal for the Scientific Study of Religion, Vol. 37 No. 2 pages 205-221.

To read two pieces that present contrasting views on the nature and purpose of a business and then to write a 1-2 page essay describing with which of the two views the student most agreed. The reading material:

- $\quad$ Friedman, Milton "The Social Responsibility of Business is to Increase Its Profits" New York Times Magazine, September 13, 1970.

- $\quad$ Handy, Charles “What is a Business For?” Harvard Business Review December 2002.

Grading information: the first essay was worth $5 \%$ of the course grade and the second essay was worth 10 $\%$ of the course grade. 


\section{Fall 2005}

Two essays: both on some aspect of an assigned supplemental book.

Purpose: to explore markets in all of their complexity.

Nature of assignment: the students were required to read, discuss, and write about the book Reinventing the Bazaar: a natural history of markets by John McMillan. The reading was divided into two parts: Chapters 1-10 and Chapters 11-17. For each part the students met in small groups (6-12) to discuss questions they submitted on the reading material. After each of the discussion periods a list of questions was distributed to the students, from which they were to choose one upon which to write a 2 page essay. ${ }^{6}$ After discussing the second part of the book the students were required to write a 2 page essay assessing the entire book. ${ }^{7}$

Grading information: each essay was worth $5 \%$ of the course grade. ${ }^{8}$

\section{REACTIONS AND COMMENTARY}

\section{Student Reactions - Overview}

Table 1: Summary of Student Reactions to the Writing Assignments (All years)

\begin{tabular}{|c|c|c|c|c|}
\hline Semester & Number of Students & Favorable & Unfavorable & No Preference \\
\hline Fall 1998 & 23 & 8.7 & 21.7 & 69.5 \\
\hline Fall 1999 & 23 & 95.7 & 4.3 & 0 \\
\hline Fall 1999 & 23 & 78.3 & 8.7 & 13 \\
\hline Fall 2000 & 27 & 66.7 & 29.6 & 3.7 \\
\hline Fall 2000 & 27 & 18.5 & 2.4 & 11.1 \\
\hline Fall 2001 & 41 & 0 & 22.2 & 97.6 \\
\hline Fall 2002 & 36 & 72.2 & 19.6 & 5.6 \\
\hline Fall 2003 & 51 & 64.7 & 26.1 & 15.7 \\
\hline Fall 2004 & 46 & 60.9 & 15.2 & 6.5 \\
\hline Fall 2004 & 46 & 78.3 & 15 & 15 \\
\hline Fall 2005 & 60 & 70 & & 21.38 \\
\hline
\end{tabular}

Table 2: Summary of Student Reactions to the Writing Assignments (Selected Years) (A given year is included only if a specific question related to the writing assignment was included as part of the course evaluation)

\begin{tabular}{|c|c|c|c|c|}
\hline Semester & Number of Students & Favorable & Unfavorable & No Preference \\
\hline Fall 1999 & 23 & 95.7 & 4.3 & 0 \\
\hline Fall 1999 & 23 & 78.3 & 8.7 & 13 \\
\hline Fall 2000 & 27 & 66.7 & 29.6 & 3.7 \\
\hline Fall 2000 & 27 & 18.5 & 70.4 & 11.1 \\
\hline Fall 2002 & 36 & 72.2 & 22.2 & 5.6 \\
\hline Fall 2003 & 51 & 64.7 & 26.1 & 15.7 \\
\hline Fall 2004 & 46 & 60.9 & 15.2 & 6.5 \\
\hline Fall 2004 & 46 & 78.3 & 15 & 15 \\
\hline Fall 2005 & 60 & 70 & & 9.29 \\
\hline Mean & & & 23.46 & 11.10 \\
\hline Median & 38 & 67.26 & 19.60 & \\
\hline
\end{tabular}


These Tables present an overview of the details described in the semester by semester student reaction data presented below. Table 1 contains all years but the mean and median for both favorable and unfavorable are biased downward in that in two of the years (1998 and 2001) the students were not specifically asked for comments on the writing assignments. Table 2 is a better indicator of the overall student reaction to the writing assignments. In some years there are two rows as the students were asked to comment separately on different assignments or were asked different types of questions. While the specific questions asked each year were not identical (year by year details are presented below) these Tables give a broad overview of student reaction. These data indicate that 2/3 of the students expressed a favorable opinion of the writing assignments.

In an attempt to derive more insight from these initiatives, the data from Table 2 has been disaggregated by separating the student responses into two categories, as noted in the description of Tables 3 and 4 below.

Table 3: Summary of Student Reactions to the Writing Assignments (Selected Years) (A given year is included only if the students were asked a specific question concerning the nature of the learning experience)

\begin{tabular}{|c|c|c|c|c|}
\hline Semester & Number of Students & Favorable & Unfavorable & No Preference \\
\hline Fall 1999 & 23 & 95.7 & 4.3 & 0 \\
\hline Fall 2002 & 36 & 72.2 & 22.2 & 5.6 \\
\hline Fall 2003 & 51 & 64.7 & 19.6 & 15.7 \\
\hline Mean & 37 & & & \\
\hline Median & 36 & 77.53 & 15.37 & 7.10 \\
\hline
\end{tabular}

Table 4: Summary of Student Reactions to the Writing Assignments (Selected Years) (A given year is included only if the students were asked a specific question about whether or not they would recommend that I use the assignment again)

\begin{tabular}{|c|c|c|c|c|}
\hline Semester & Number of Students & Favorable & Unfavorable & No Preference \\
\hline Fall 1999 & 23 & 78.3 & 8.7 & 13 \\
\hline Fall 2000 & 27 & 66.7 & 29.6 & 3.7 \\
\hline Fall 2000 & 27 & 18.5 & 70.4 & 11.1 \\
\hline Fall 2004 & 46 & 60.9 & 26.1 & 13 \\
\hline Fall 2004 & 46 & 78.3 & 15.2 & 6.5 \\
\hline Fall 2005 & 60 & 70 & 15 & 15 \\
\hline Mean & & & 27.50 & 10.38 \\
\hline Median & 38 & 62.12 & 20.65 & 12.05 \\
\hline
\end{tabular}

The data in Tables Three and Four allow for several interesting questions to be addressed.

Question \#1: $\quad$ Does it make a difference which way you ask for the specific feedback - learning experience versus use again?

This can be answered by comparing the mean values of favorable and unfavorable in Table 3 versus Table 4. Students seem more inclined to have a favorable opinion of an assignment when asked if they found it was thought-provoking/worthwhile/effective than if asked whether or not they would recommend it being used again. This is evidenced by mean favorable values of 77.53 in Table 3 compared to a mean favorable value of 62.12 in Table 4. This conclusion is further supported by data from the only semester in which I asked the students both types of questions (Fall 1999). Compare the $95.7 \%$ favorable from Table 3 with the $78.3 \%$ favorable from Table 4.

Question \#2: $\quad$ Does it make a difference if you have essays based on specific assigned material or not? 
The only two years during which the essays were not based on specific assigned material are Fall 2002 and Fall 2003. Unfortunately during these years I did not ask the students whether or not the assignments should be used again. This makes it difficult to discern any direct answer to this question. However the larger percentage of unfavorable responses for Fall 2002 and Fall 2003 compared to the small unfavorable response for Fall 1999 in Table 3 does suggest that students have a preference for being given assignments based on specific material. ${ }^{9}$

Question \#3: Are there any obvious outliers?

There clearly is one obvious outlier; the first assignment from Fall 2000, which has an unfavorable response percentage almost three times larger than the mean. What might be the reason for this? It seems possible that this is due to the difference in required reading for each of the two assignments given in Fall 2000. Each counted for the same percentage of the course grade but the second assignment required 60 pages of reading whereas the first assignment required only 15 pages of reading. Indeed students commented that the reading material for the second assignment was too long, too hard, or too boring.

\section{Student Reactions - by semester}

Fall $1998(\mathbf{N}=23)$

Students were not asked any specific questions relating to the writing assignments. Reaction is assessed by reading comments on the course evaluation forms.

$\begin{array}{ll}\text { Positive Comment on the assignments } & 8.7 \% \\ \text { Negative Comment on the assignments } & 21.7 \% \\ \text { Neutral Comment on the assignments } & 4.3 \% \\ \text { No Comment on the assignments } & 65.2 \%\end{array}$

These data clearly demonstrate that you are unlikely to get feedback on any particular part of the course unless you specifically ask for it. (This is further illustrated by the results from Fall 2001 below.)

Fall $1999(\mathbf{N}=\mathbf{2 3})$

Students were asked two questions specifically related to the writing assignment.

Q1 Did you find the essay assignment to be a thought-provoking experience? Why or why not?

Yes $\quad 95.7 \%$

No $\quad 4.3 \%$

Q2 Would you recommend that I use the essay assignment again the next time I teach the course? Why or why not?

Yes $\quad 78.3 \%$

No $\quad 8.7 \%$

No preference $\quad 13.0 \%$

The commentary by the students suggests that while they found the assignment thought provoking it was perhaps too much so. Several commented that it was too much work for the percentage of the course grade. In addition there were pleas from several students for more clarity in terms of the purpose and grading of the assignments.

Fall $2000(\mathbf{N}=27)$

Students were asked a question specifically related to each of the writing assignments. 
Q1 Would you recommend that I use the Hayek essay assignment again? Why so or why not?

$\begin{array}{ll}\text { Yes } & 66.7 \% \\ \text { No } & 29.6 \% \\ \text { No preference } & 3.7 \%\end{array}$

Q2 Would you recommend that I use "On the limited nature of the standard microeconomic theory of the firm" essay assignment again? Why so or why not?

$\begin{array}{ll}\text { Yes } & 18.5 \% \\ \text { No } & 70.4 \% \\ \text { No preference } & 11.1 \%\end{array}$

As with the Fall 1999 reaction, student commentary described dissatisfaction with the amount of required reading material for the assignments. The students seem to have some sort of inherent "fairness meter" by which they measure the amount of effort per assignment relative to the percentage of the grade associated with the assignment. While the exact readings on this meter may be unknowable, it appears that the Fall 1999 and Fall 2000 assignments are examples of assignments that push the needle on the meter to "unfair" while the other assignments avoid this meter reading.

Fall $2001(N=41)$

Students were not asked any specific questions relating to the writing assignments. Reaction is assessed by reading comments on the course evaluation forms.

Positive Comment on the assignments $\quad 0.0 \%$

Negative Comment on the assignments $\quad 2.4 \%$

Neutral Comment on the assignments $\quad 0.0 \%$

No Comment on the assignments $\quad 97.6 \%$

Fall $2002(\mathbf{N}=36)$

Students were asked a question specifically related to the writing assignments.

Explain whether you agree or disagree with the following statement: "I feel the essay assignments were a worthwhile learning experience."

$\begin{array}{ll}\text { Agree } & 72.2 \% \\ \text { Disagree } & 22.2 \% \\ \text { No Preference } & 5.6 \%\end{array}$

Some students commented that they thought the two page size limit was a good thing. The responses from these students yielded what is perhaps the most interesting comment of all: "I think you should scratch the whole essay idea. This is Econ 308 not Writing 101."

Fall $2003(\mathbf{N}=51)$

Students were asked a question specifically related to the writing assignments.

Were the essay assignments an effective learning experience for you? Why or why not?

$\begin{array}{ll}\text { Yes } & 64.7 \% \\ \text { No } & 19.6 \% \\ \text { No Preference/Opinion } & 15.7 \%\end{array}$


Several students commented on how the assignments were helpful in that they allowed for the linking of the theory with the real world.

Fall $2004(N=46)$

Students were asked a question specifically related to each of the writing assignments.

Q1 Would you recommend that I assign the paper on Mother Teresa the next time I teach the class? Why or why not?

$\begin{array}{ll}\text { Yes } & 60.9 \% \\ \text { No } & 26.1 \% \\ \text { No preference/Opinion } & 13.0 \%\end{array}$

Q2 Would you recommend that I assign the papers by Friedman or Handy the next time I teach the course? Why or why not?

$\begin{array}{ll}\text { Yes } & 78.3 \% \\ \text { No } & 15.2 \% \\ \text { No preference/Opinion } & 6.5 \%\end{array}$

Several students indicated that the two page length maximum for the essays was not sufficient - it was too short.

Fall $2005(N=60)$

Students were asked three questions specifically related to the writing assignments.

Q1 Would you recommend that I have students read Reinventing the Bazaar the next time I teach this course? Why so or why not?

Yes $\quad 91.7 \%$

No $\quad 8.3 \%$

No preference/Opinion $\quad 0.0 \%$

Q2 If you answered YES to question (1) above, would you recommend that students participate in small group discussion sections on Reinventing the Bazaar the next time I teach this course? Why so or why not?

Yes $\quad 75.0 \%$

No $11.7 \%$

No preference/Opinion $\quad 13.3 \%$

Q3 If you answered YES to question (1) above, would you recommend I have students write short essays on Reinventing the Bazaar the next time I teach this course? If so, of what type (the same as you wrote or some other)? If not, why not?

$\begin{array}{ll}\text { Yes } & 70.0 \% \\ \text { No } & 15.0 \% \\ \text { No preference/Opinion } & 15.0 \%\end{array}$

Several students indicated that the best part of the assignment was that the reading material had many examples that related theory to the real world. Interestingly, even though this assignment contains the most amount of additional reading, few if any students complained about the length. This is likely due to two factors. First, while not jargon free, the degree of difficulty in reading (comprehending) is far lesser than the journal articles from other 
assignments. Second, the various assignments associated with reading the book accounted for a sizeable portion of the course grade $(15 \%)$.

\section{CONCLUSION}

What to make of all of this? I think some lessons can be drawn:

- If you want feedback on specific assignments, ask for it.

- $\quad$ Be excruciatingly clear in your description of the assignment.

- $\quad$ Students possess some sort of inherent (internal) fairness meter concerning the work-to-credit-given ratio.

- Students will complain if a paper they have to write is "too short."

- The more the assignment allows the students to link theory to the real world the more they will like it.

- If you want to undertake a systematic analysis of various assignments over many semesters, give some thought to how you will assess the results BEFORE you give the assignments.

- $\quad$ Reflect on the success or lack thereof immediately after each semester. game theory. ${ }^{10}$

Are the lessons obvious? Perhaps. But what comes to mind is something David Kreps has written about

"Few if any of the conclusions of successful game theoretic analyses are startling or mysterious or arcane; after the fact, it is usually easy to say 'Well, I think I already knew that.' Of course, what one remembers having known before an explanation was offered is often more than what one really did know. Perhaps it is more truthful after the fact to be saying 'I knew that subconsciously' or 'I should have known that; it's so obvious."

I think we can safely substitute the words "successful writing assignments" for "game theoretic analyses" in the first sentence of this quote.

\section{AUTHOR BIO}

Patrick B. O'Neill is Professor and Chair of the Department of Economics at the University of North Dakota. He received his $\mathrm{PhD}$ in Economics from Boston College in 1987. His main teaching interests are Intermediate Microeconomic Theory, Managerial Economics, and Government and Business. His research interests include the scholarship and teaching of economics, industry and firm studies, as well as happiness and economics.

\section{REFERENCES}

1. Bolton, Patrick and Scharfstein, David S. "Corporate Finance, The Theory of the Firm, and Organization" Journal of Economic Perspectives, Vol. 12 No. 4 Fall 1998 pages 95-114.

2. Chandler, Alfred D. "Organizational Capabilities and the Economic History of the Industrial Enterprise" Journal of Economic Perspectives, Vol. 6 No. 3 Summer 1992 pages 79-100.

3. Frank, Robert. Microeconomics and Behavior, fourth edition, Irwin-McGraw Hill, 2000.

4. Friedman, Milton "The Social Responsibility of Business is to Increase Its Profits" New York Times Magazine, September 13, 1970.

5. Handy, Charles "What is a Business For?" Harvard Business Review, Vol. 80 No. 12 December 2002, pages 49-55.

6. Hayek, Frederick “The Meaning of Competition" Chapter 5 in Individualism and Economic Order, University of Chicago Press, 1948, pages 92-106.

7. Kreps, David. Game Theory and Economic Modelling, Oxford University Press, 1990

8. Kwilecki, Susan and Loretta S. Wilson "Was Mother Teresa Maximizing Her Utility? An Idiographic Application of Rational Choice Theory" Journal for the Scientific Study of Religion, Vol. 37 No. 2 pages 205-221.

9. McMillan, John. Reinventing the Bazaar: a natural history of markets, Norton, 2002.

10. Nelson, Richard R. "Why Do Firms Differ, and How Does It Matter?" Strategic Management Journal, Vol. 12 Winter 1991 pages 61-74. 
11. Penrose, Edith "The Firm in Theory" in The Theory of the Growth of the Firm 3e Oxford University Press, 1995, pages 9-30.

12. Rabin, Matthew "Psychology and Economics" Journal of Economic Literature, Vol. 36 March 1998, pages 11-46.

13. Rhoads, Steven A. "The Economist's Consumer and Individual Well-Being" Chapter 9 in The Economist's View of the World, Cambridge University Press, 1985, pages 143-178.

14. Spulber, Donald F. "Economic Analysis and Management Strategy: A Survey" Journal of Economics and Management Strategy, Vol. 1 No. 3 Fall 1992, pages 535-574.

15. Williamson, Oliver E. "The Modern Corporation: Origins, Evolution, and Attributes" Journal of Economic Literature, Vol. 19 December 1981, pages 1537-1568.

\section{ENDNOTES}

\footnotetext{
${ }^{1}$ Indeed the instructor also gave us the required paper topic: On the Representational Nature of Utility.

${ }^{2}$ There are many papers describing the use of writing in economics courses in various issues of the Journal of Economic Education. A good first place to begin is "Integrating the Practice of Writing Into Economics Instruction" by W. Lee Hansen, Chapter 5 in Teaching Economics to Undergraduates: Alternative to Chalk and Talk, edited by William E. Becker and Michael Watts, Edward Elgar, 1998.

${ }^{3}$ UND is a Carnegie Category II institution. The Department of Economics is located in the College of Business and Public Administration. Intermediate Microeconomic Theory is a required course for students majoring in Economics, Business Economics, or Banking and Financial Economics. In addition, many students majoring in Accounting, Entrepreneurship, or Finance take the course.

${ }^{4}$ Perhaps this is a primarily a function of the number of students I have and my increasing reluctance to read filler. I teach two sections of the course each fall semester with a typical enrollment of 25-35 students per section.

${ }^{5}$ The actual assignment sheets, including the grading rubrics used for each, are available upon request.

${ }^{6}$ The students were only required to write an essay after the discussion of either part 1 or part 2 of the book, but not both.

${ }^{7}$ The students were told to imagine that upon graduation their boss asked them to provide a summary and recommendation as to whether or not the book should be read.

${ }^{8}$ The original weighting of $5 \%$ per essay was modified during the semester. The students were given the option of skipping the first essay and putting all $10 \%$ weight onto the second essay.

${ }^{9}$ This conclusion must be viewed cautiously since in Fall 1999 the students were asked if the assignment was thought-provoking whereas in Fall 2002 and Fall 2003 the students were asked if they felt the assignments were worthwhile or effective learning experiences. Thus the percentage of unfavorable responses is not measuring exactly the same thing in each of the years.

${ }^{10}$ David Kreps, Game Theory and Economic Modelling, Oxford University Press, 1990, page 88.
} 


\section{NOTES}

